\title{
Sensitivity of aerosol radiative forcing to various aerosol parameters over the Bay of Bengal
}

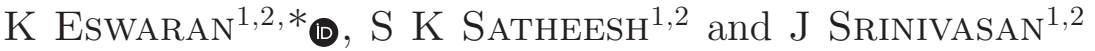 \\ ${ }^{1}$ Centre for Atmospheric and Oceanic Sciences, Indian Institute of Science, Bangalore, India. \\ ${ }^{2}$ Divecha Centre for Climate Change, Indian Institute of Science, Bangalore, India. \\ *Corresponding author. e-mail: kruthika.eswaran89@gmail.com
}

MS received 12 July 2018; revised 6 January 2019; accepted 14 February 2019; published online 17 June 2019

In the shortwave solar spectrum $(0.25-5 \mu \mathrm{m})$, radiation is affected by the change in various aerosol properties and also by water vapour and other gas molecules. The presence of a variety of aerosols over the Bay of Bengal (BoB) during different seasons results in a change in aerosol properties, including the aerosol layer height. The BoB is an integral part of the Indian monsoon, and hence it is essential to understand the radiation budget over the BoB. The sensitivity of the aerosol forcing due to the changes in aerosol properties and other parameters has been studied using the Santa Barbara discrete ordinates radiative transfer model. The aerosol forcing at the top of the atmosphere was found to depend on the aerosol loading (aerosol optical depth), aerosol type (single scattering albedo) and the angular distribution of the scattered radiation (asymmetry parameter). The analysis also shows the presence of a relationship between aerosol layer height and the total amount of water vapour present in the atmosphere. The present study highlights the need for better retrievals of vertical aerosol distribution and water vapour profiles for a better understanding of the role of aerosols in the climate.

Keywords. Sensitivity analysis; aerosol radiative forcing; SBDART; aerosol layer height.

\section{Introduction}

The perturbation of the radiation balance can affect the global climate through changes in the temperature and precipitation. (Mitchell 1983; Mitchell et al. 1987, 1999; Boer 1993; Hansen et al. 1997; Allen and Ingram 2002). Atmospheric components like aerosols, clouds and greenhouse gases (GHGs) modify the radiation balance by interacting with radiation (Coakley et al. 1983; Coakley and Cess 1985; Ramanathan et al. 1989; Houghton et al. 1990; Charlson et al. 1992, 2005; Kiehl and Briegleb 1993; Hansen et al. 2005). Most of the global warming is due to the increase in the emission of GHG since industrialisation. The role of aerosols in human-induced climate change is not understood well (Hansen et al. 1998, 2000; IPCC 2013). The change in the radiative flux at the top of the atmosphere (TOA) with and without aerosols is called aerosol radiative forcing $\left(\mathrm{ARF}_{\mathrm{TOA}}\right)$ (Charlson et al. 1992; Satheesh and Ramanathan 2000). Uncertainty in aerosol forcing is mainly due to the significant variation of the chemical composition of aerosols over space and time. Reducing the uncertainty in aerosol forcing by at least three times can help reduce the uncertainty in climate sensitivity (Schwartz 2004). The aerosol forcing depends on both the direct aerosol effects (Penner et al. 1994; Ramanathan and Carmichael 2008; Boucher et al. 2013) and the indirect aerosol effects (Knutti 
et al. 2002; Quaas et al. 2006; Lohmann et al. 2007; Anderson et al. 2010; Curry and Webster 2011; Tao et al. 2012; Lin et al. 2014; Rosenfeld et al. 2014; Lee et al. 2015). It also depends on the spatial-temporal variation of aerosol properties as well on various processes during the aerosol-cloudclimate feedback (Li et al. 2009; Carslaw et al. 2010; Kokhanovsky et al. 2010; Raes et al. 2010).

According to figures 8.15, 8.16 and section 7.5 of the IPCC (2013) report, there is 'high confidence' regarding the magnitude of the global mean total aerosol forcing $\left(-0.9 \mathrm{~W} \mathrm{~m}^{-2}\right)$ which includes aerosol-radiation and aerosol-cloud interaction. Aerosols were found to offset a portion of the radiative forcing $\left(2.83 \mathrm{~W} \mathrm{~m}^{-2}\right)$ due to GHGs. Aerosols also contribute to the largest uncertainty in the total radiative forcing estimate. The present study on direct aerosol forcing is over oceans in the absence of clouds. The presence of clouds makes the aerosol-radiation interaction more complex along with the additional effect of aerosols on cloud properties (Twomey 1991; Curry 1995; Breon et al. 2002; Lohmann and Lesins 2002; Kaufman et al. 2005; Kaufman and Koren 2006; Yu and Zhang 2013). The global mean direct ARF is currently estimated to be $-0.35 \mathrm{~W} \mathrm{~m}^{-2}(-0.85$ to +0.15$)$ (Myhre et al. 2013). This estimate was found to be smaller in magnitude compared to the previous estimate of $-0.5 \mathrm{~W} \mathrm{~m}^{-2}(-0.9$ to -0.1$)$ given in the previous climate assessment report. The estimate of direct aerosol forcing by IPCC (2013) is more robust than the previous report due to better agreement between models and observationbased estimates (Boucher et al. 2013). Following the IPCC report, there have been studies showing that aerosol forcing is less negative than estimated earlier albeit with uncertainties (Samset et al. 2014; Stevens 2015; Chung et al. 2016).

Aerosol properties used in radiative transfer calculations can either be modelled or retrieved from observations. The difference in these properties results in a difference between model-based and observed radiative forcing (McComiskey et al. 2008; Myhre 2009; Loeb and Su 2010; Chen et al. 2011; Kahn 2012). Closure studies have been done validating model-simulated forcing values with observation results (Halthore and Schwartz 2000; Halthore et al. 2005; Michalsky et al. 2006). The discrepancies between the model-based and observed values were due to the representation of various components of radiative transfer. However, the errors due to radiative transfer were much smaller compared to those due to the uncertainty in aerosol properties (McComiskey et al. 2008). The study by Michalsky et al. (2006) showed the sensitivity of radiative model estimates due to the change in aerosol optical depth (AOD). McComiskey et al. (2008) further reported that reducing the measurement uncertainty of any environmental parameter including aerosols increased the accuracy in the estimation of direct radiative forcing. Advanced remote sensing and better satellite algorithms have resulted in the reduction of uncertainty.

Earlier studies on the radiative effects of aerosols showed the sensitivity of anthropogenic sulphate and soot forcing to aerosol size, aerosol composition, relative humidity and vertical profile of aerosols (Nemesure et al. 1995; Schwartz 1996; Haywood and Ramaswamy 1998). Using a one-dimensional column radiation model, Liao and Seinfeld (1998) found that clear-sky shortwave forcing by mineral dust depended on aerosol loading, the imaginary part of the refractive index which represents absorption, and also dust particle size. Better measurements of AOD improve the aerosol forcing estimated by models. However, the uncertainties due to the single scattering albedo (SSA), aerosol composition and the vertical profile of aerosols are still significant (McComiskey et al. 2008; Loeb and Su 2010; Zarzycki and Bond 2010; Heintzenberg et al. 2011; Vuolo et al. 2014; Feng et al. 2015). More measurements are required across the globe for a better understanding of the impact of these properties on aerosol forcing and also for better validation of model estimates. Clear-sky ARF over the oceans is usually negative at the TOA (Bellouin et al. 2005; Loeb and Manalo-Smith 2005; Yu et al. 2006; Myhre et al. 2007; Boucher et al. 2013). However, it can become positive when aerosol absorption increases, i.e., SSA decreases, upscatter fraction decreases or if the albedo of the underlying surface increases. Loeb and $\mathrm{Su}$ (2010) showed that errors of \pm 0.06 in SSA over oceans (Dubovik et al. 2000) result in an error of $0.5-1 \mathrm{~W} \mathrm{~m}^{-2}$ uncertainty in forcing.

Aerosol forcing undercloud-free conditions and the estimation of shortwave aerosol direct forcing for different types of aerosols have been studied using observations and models over oceans and land (Bergamo et al. 2008; Di Biagio et al. 2010; Bauer et al. 2011; Osborne et al. 2011). Remer and Kaufman (2006) used aerosol data from the moderate imaging spectroradiometer (MODIS) sensor to estimate the aerosol direct radiative effect over cloud-free oceans. A detailed review of various 
measurements of aerosol direct radiative effect and forcing is given in $\mathrm{Yu}$ et al. (2006). The synergistic use of data sets from clouds and Earth's radiant energy system (CERES) and MODIS was used by Christopher and Zhang (2002) to estimate the shortwave aerosol direct radiative effect over oceans. However, one of the major uncertainties was due to the lack of angular distribution models (ADMs) for aerosols. A list of observational studies specific to biomass burning regions is given in table 2 of Patadia and Christopher (2014). Most of these studies improved the existing ADMs to reduce the uncertainty in aerosol forcing estimation. However, unlike Patadia and Christopher (2014), the ADMs they used did not account for aerosols thereby underestimating forcing by $3 \mathrm{~W} \mathrm{~m}^{-2}$. These newly developed empirical models are useful in modelling studies of aerosols (Zhang et al. 2005; Christopher and Jones 2008; Patadia and Christopher 2014). They have also highlighted the need to study the aerosol radiative effect from different sensors to verify modelling simulations.

The Bay of Bengal (BoB) is an oceanic region surrounded by land masses and industrialised areas on three sides. Since the BoB plays a vital role in the evolution of the Indian summer monsoon, changes in $\mathrm{ARF}_{\mathrm{TOA}}$ over this region can have a crucial impact on the regional climate. The aerosols over the BoB vary with season - from being highly absorbing during winter (DecemberJanuary-February) to a mixture of anthropogenic aerosols and dust during March-April-May and to mostly scattering aerosols (June-July-August and September-October-November). Studies have shown that over the BoB, there is a strong latitudinal gradient of aerosols (north-south) during all seasons (Satheesh et al. 2006b; Nair et al. 2009, 2013). While continental aerosols (from central and eastern India) dominated the northern BoB, East Asia and the oceanic regions influenced the southern BoB (Satheesh et al. 2006b).

Detailed studies have been carried out regarding the heterogeneity of aerosols and aerosol loading over the BoB for different seasons (Moorthy et al. 2003, 2008, 2010; Kumar et al. 2011, 2013). During the W-ICARB (Winter Integrated Campaign for Aerosols, Gases and Radiation Budget) field experiment during December 2008 and January 2009, it was found that there was an abundance of fine mode aerosols (highly absorbing), mostly of anthropogenic origins from the nearby continents (Moorthy et al. 2010; Kaskaoutis et al. 2011; Kumar et al. 2013). These aerosols are mainly confined to the boundary layer (BL) due to the sources being near. However, during spring and summer, the region is dominated by aerosols that have been transported over long distances (Satheesh et al. 2006a; Niranjan et al. 2007). The wind directions are mainly north-westerlies resulting in the transport of dust from the desert regions of western India, Arabian Peninsula and the Sahara. Most of these aerosols are at the height of 3-4 km and are a mixture of biomass from South East Asia, dust from nearby continents and few marine aerosols (Satheesh et al. 2006a, 2008; Babu et al. 2008). During the ICARB experiment, performed during March-May 2006, vertical profiles of black carbon (BC) was measured and was found to be of local origin within the $\mathrm{BL}$, and the $\mathrm{BC}$ above the $\mathrm{BL}$ was due to long-range transport and non-local origins (Babu et al. 2008). These cruise studies also analysed the spatial variation of the aerosol properties during the cruise period.

The present study uses modelling simulations to understand the various aerosol properties that affect the aerosol forcing over the BoB for 2 months representing the two seasons - winter and premonsoon. Water vapour amount and the mean aerosol layer height varied over the BoB between the seasons. The effect of variation in both these parameters on the aerosol forcing was also studied using model simulations. Finally, using a simple analytical model, the role of aerosol layer height on the reflected flux at the TOA was studied.

\section{Methodology}

The BL height for winter and pre-monsoon over the BoB has been found to be varying from $500 \mathrm{~m}$ to $1 \mathrm{~km}$ (Subrahamanyam et al. 2012; Lakshmi et al. 2017). Since the present study is a model analysis of factors affecting the aerosol forcing, two profiles representing aerosols within the BL (during winter - January) and aerosols above the BL (during premonsoon - May) have been used (figure 1a). The profiles were simulated assuming Gaussian distribution and corrected with MODIS AOD (averaged 2011-2016). Figure 1(b) shows the percentage of aerosol loading present above at each height. The majority of the aerosol loading was closer to the surface during January and above $1 \mathrm{~km}$ during May. The aerosol loading is similar to the one observed by Lakshmi et al. (2017) (figures 3 and 4).

The different types of aerosols, as well as the variation in aerosol properties between seasons, 

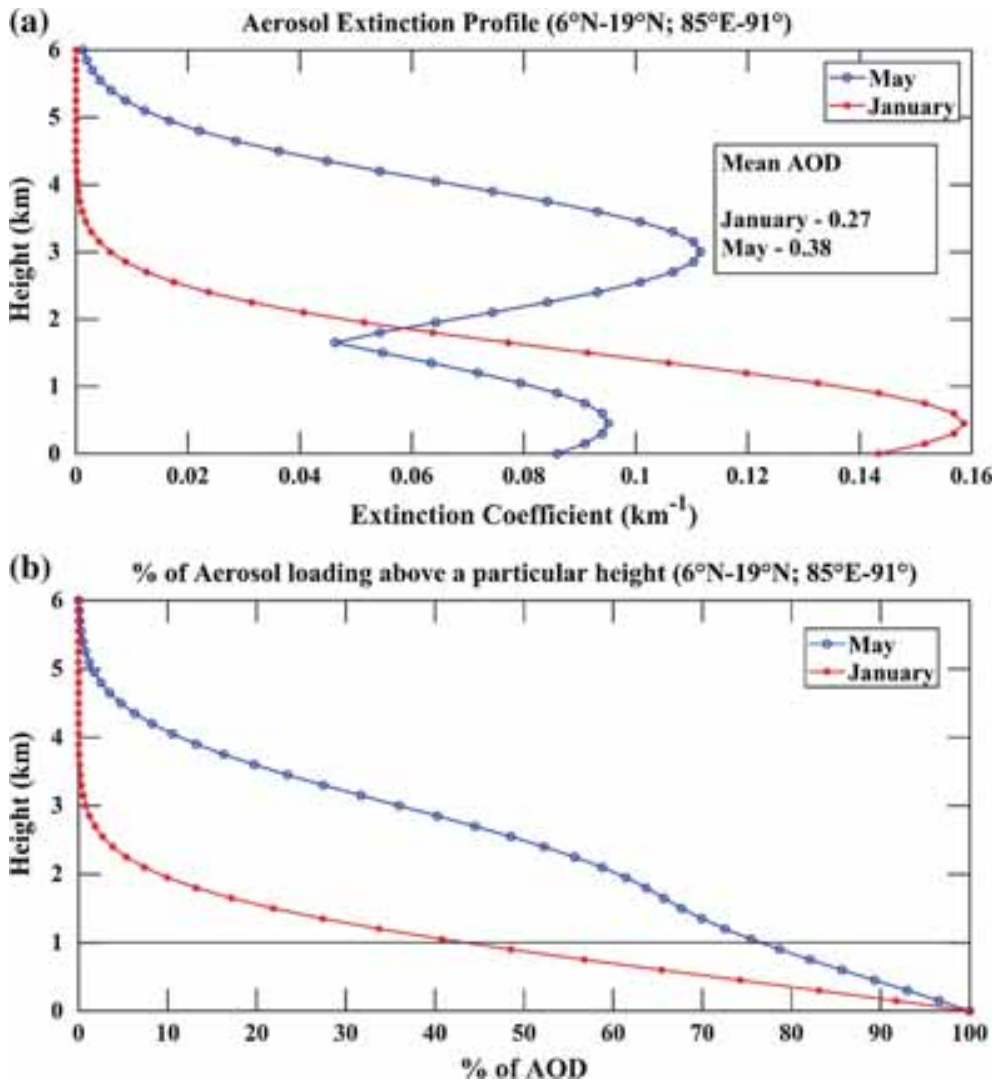

Figure 1. (a) Two ideal profiles over the $\mathrm{BoB}\left(6-19^{\circ} \mathrm{N} ; 85-91^{\circ} \mathrm{E}\right)$, corrected with MODIS AOD, representing aerosols closer to the surface (January) and at a higher altitude (May). (b) The percentage of aerosol loading present above each height. Mean AOD of January and May are used. The majority of the aerosol loading is closer to the surface during January and above $1 \mathrm{~km}$ during May.

affect the ARF. The sensitivity of aerosol forcing to a particular parameter $\left(S_{\text {unitp }}\right)$ is given as

$$
S_{\text {unitp }}=\partial F / \partial p,
$$

where $\partial F$ is the change in aerosol forcing and $\partial p$ is the change in the respective parameter. However, over the $\mathrm{BoB}$, the range $R$ (maximumminimum) of each parameter for different months is not unity. Hence to accommodate the variation of each parameter during each month, the sensitivity $S_{\text {unitp }}$ is multiplied with the range of different aerosol parameters to get the actual sensitivity of aerosol forcing $(S)$. The range of aerosol properties and water vapour was calculated using the latest versions of MODIS and ozone monitoring instrument (OMI) data. The column water vapour and surface albedo were taken from MODIS and CERES, respectively. The asymmetry parameter was taken from MODIS v5.1 data since this parameter has been discontinued for the later versions. The estimated range values over the $\mathrm{BoB}\left(6-19^{\circ} \mathrm{N}\right.$ and $\left.85-91^{\circ} \mathrm{E} ; 2011-2016\right)$ are shown in table 1.
Table 1. Range of aerosol and environment parameters during January and May.

\begin{tabular}{lcc}
\hline Parameter & January & May \\
\hline AOD & 0.246 & 0.463 \\
AE & 0.344 & 0.371 \\
Asymmetry factor & 0.047 & 0.046 \\
SSA & 0.057 & 0.042 \\
PW (cm) & 2.271 & 1.848 \\
Surface albedo & 0.005 & 0.005
\end{tabular}

The range is calculated as the difference between the maximum and minimum value of the respective parameter over the $\mathrm{BoB}\left(6-19^{\circ} \mathrm{N} ; 85-91^{\circ} \mathrm{E}\right)$ throughout 6 yrs (2011-2016).

For example, the value 0.374 for AOD during May represents not the mean value but the range, or, in other words, the difference between the maximum and minimum value of $\mathrm{AOD}$ over the $\mathrm{BoB}$ during May.

The model used in the study is the Santa Barbara DISORT radiative transfer (SBDART) model (Ricchiazzi et al. 1998) which uses planeparallel radiative transfer and calculates fluxes 
using the discrete ordinates radiative transfer (DISORT) method at the TOA, surface and within the atmosphere for different physical conditions. Fluxes in the SBDART model were calculated, using four radiation streams, in the wavelength band $0.25-5 \mu \mathrm{m}$. The aerosol properties used in this study were given at a wavelength of $550 \mathrm{~nm}$. The properties include AOD and SSA. AOD is defined as the amount of radiation attenuated when it passes through a layer of aerosol. Other important properties included are Angstrom exponent (AE) - which represents the spectral dependence of AOD (Angstrom 1929) and the asymmetry parameter - defined as the phase function-weighted average cosine of the scattering angle. Apart from these properties, the aerosol vertical profile, columnar water vapour content (PW) and the surface albedo were also used as input to the model. SSA - defined as the ratio of scattering efficiency to total extinction efficiency - was assumed to be spectrally uniform, and the fluxes estimated were diurnally averaged. The simulations used the tropical atmosphere provided by SBDART and spectrally uniform surface albedo. The values of all the properties are shown in table 2 . For a change in a particular property, the other

Table 2. Different values of properties used in simulations along with their constant default value.

\begin{tabular}{llc}
\hline Property & \multicolumn{1}{c}{ Range } & Default value \\
\hline AOD & {$[0.2,0.4,0.6,0.8,1]$} & 0.4 \\
AE & {$[0.5,1]$} & 1 \\
Asymmetry factor & {$[0.55,0.65,0.75]$} & 0.65 \\
Surface albedo & {$[0.06,1]$} & 0.06 \\
PW $(\mathrm{cm})$ & {$[0,2,4,6]$} & 4 \\
SSA & {$[0.86,0.96]$} & Both values used \\
\hline
\end{tabular}

properties were kept constant. The default values of these properties are also shown below in table 2 . Various cases were used under varying conditions to simulate the effect of change of each parameter on the change in ARF. The cases are summarised in table 3 .

\section{Results}

The sensitivity of ARF due to the change in various aerosol and environment parameters for all the cases was calculated and is shown in figure 2 .

The legend in the above figure represents the values between which parameters varied (e.g., AOD changed from 0.4 to 1 , and the effect of this change was calculated based on the change in ARF). The four cases 1-4 each represent a type of aerosol and a vertical profile of aerosol (table 3). The first two cases represent the month of January when aerosols are present mainly within the $\mathrm{BL}$ at $\sim 0.5 \mathrm{~km}$ (figure 1). SSA of 0.86 and 0.96 are used in cases 1 and 2 , respectively, to see the effect of aerosol type on the sensitivity of ARF due to the change in other parameters. The last two cases represent similar conditions for May when the region was dominated by elevated aerosols like dust that are transported over long distances. From figure 2(a), it can be seen that irrespective of the season and type of aerosol, the maximum sensitivity of ARF was seen due to change in AOD which is a measure of the aerosol loading in the atmosphere. Depending on the type of aerosol, some amount of radiation reflected back to space and some was absorbed by the aerosol. Based on the underlying surface albedo, the radiation from the surface also interacts with the aerosol layer present above (Haywood and Shine 1995). Over surfaces which have low surface albedo, the

Table 3. Various cases used in the simulations.

\begin{tabular}{|c|c|c|}
\hline Case \# & Description & Remarks \\
\hline 1 & January profile, SSA 0.86 & \multirow{4}{*}{$\begin{array}{l}\text { To calculate the sensitivity of ARF due to the } \\
\text { change in AOD, AE, asymmetry factor, PW, } \\
\text { surface albedo (figure } 2 \text { ) }\end{array}$} \\
\hline 2 & January profile, SSA 0.96 & \\
\hline 3 & May profile, SSA 0.86 & \\
\hline 4 & May profile, SSA 0.96 & \\
\hline 5 & January profile, $\mathrm{PW} 0 \mathrm{~cm}$ & \multirow{4}{*}{$\begin{array}{l}\text { To calculate the sensitivity of ARF due to the } \\
\text { change in SSA (figure } 3 \text { ) }\end{array}$} \\
\hline 6 & January profile, $\mathrm{PW} 4 \mathrm{~cm}$ & \\
\hline 7 & May profile, $\mathrm{PW} 0 \mathrm{~cm}$ & \\
\hline 8 & May profile, PW $4 \mathrm{~cm}$ & \\
\hline
\end{tabular}

The first four represent the aerosol profile for both months for absorbing and scattering aerosols. The next four cases represent the 2 months but for dry and wet atmosphere. 


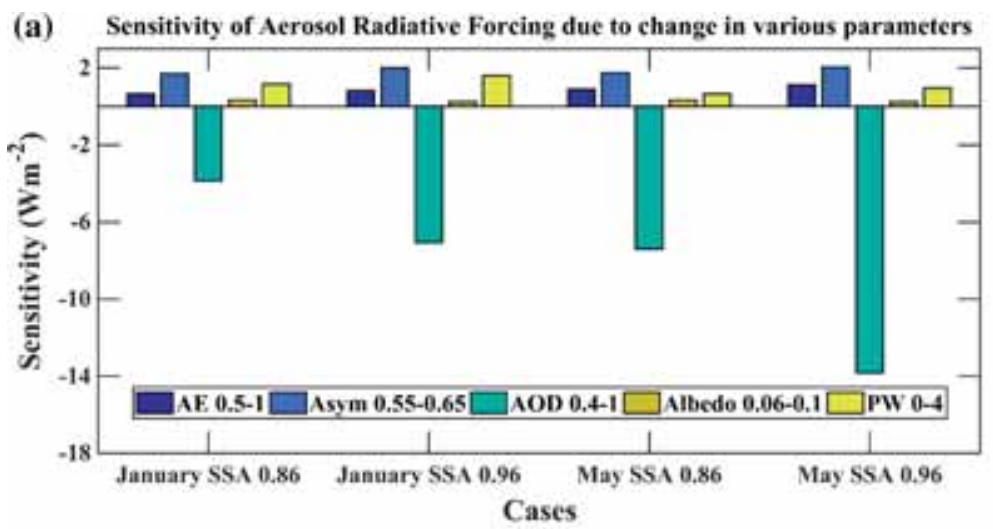

(b) Sensitivity of Aerosol Radiative Foreing due to change in various parameters

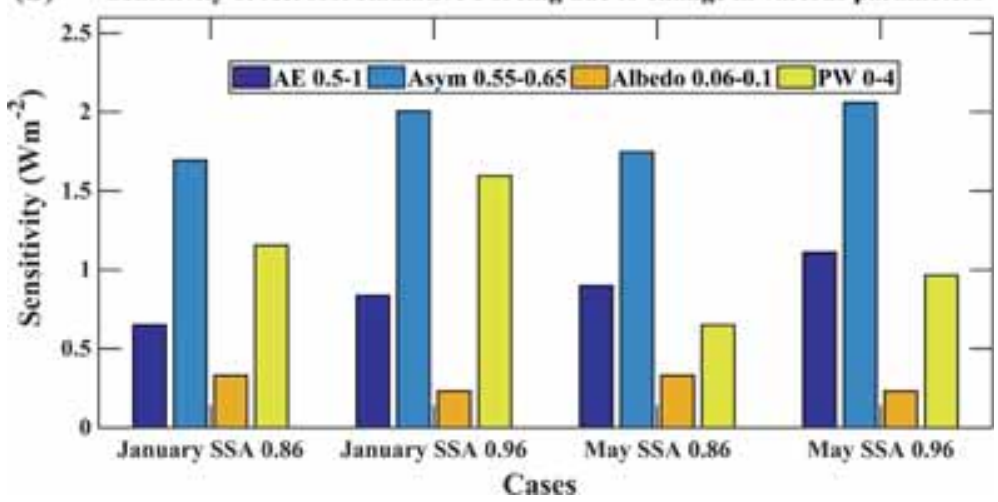

Figure 2. (a) Sensitivity of aerosol forcing due to the change in various aerosol and environment parameters and (b) sensitivity of aerosol forcing due to the change in various parameters (same as a) without showing sensitivity to AOD.

flux at the TOA in the presence of aerosols is more than pristine sky (aerosol free) due to the reflected radiation from the aerosol layer, which results in a negative forcing (cooling) at the TOA. Over land and surfaces with high albedo, an aerosol layer with low SSA absorbs radiation reflected from the surface thus heating the atmosphere and resulting in a lesser flux at the TOA (Seinfeld and Pandis 2006). Aerosols with higher SSA reflect more radiation to the space resulting in a more negative forcing at the TOA compared to aerosols with lower SSA. Hence over oceans, as AOD increases, the effect of the aerosols on the TOA forcing also increases and those with higher SSA show a higher effect than those with lower SSA. The sensitivity to AOD is slightly higher during May due to the large variation of aerosol loading which can be due to the presence of a large number of dust aerosols transported over long distances over northern and central BoB (table 1). The same simulations in figure 2(a) are shown in figure 2(b) without showing the sensitivity to AOD.

For an aerosol with fixed SSA, the major sensitivity factors from figure 2(b) are the asymmetry factor, followed by $\mathrm{AE}$ and water vapour. In simple terms, the asymmetry parameter is defined as the amount of radiation scattered in the forward direction. An asymmetry value of 1 implies that radiation is purely forward scattering and a value of -1 means it is entirely back-scattering. As the asymmetry factor increases, the forward scattering also increases resulting in lesser flux at the TOA. Aerosol size distribution is the main factor controlling the value of the asymmetry parameter. Aerosol composition does not affect the asymmetry parameter directly. Instead, it influences the hygroscopic growth and hence the size of the aerosol particle (Andrews et al. 2006). Andrews et al. (2006) derived the asymmetry parameter using various methods. Over the Southern Great Plains, the authors found a systematic increase in the asymmetry parameter with SSA (figure 5; Andrews et al. 2006). The increase was attributed to the removal of large, hygroscopic particles due to wet scavenging leaving only particles with high backscattering efficiency (low asymmetry parameter) and highly absorbing aerosols (low SSA) in the atmosphere.

A change in the asymmetry parameter has a larger effect on the TOA forcing for scattering aerosols than absorbing aerosols. Hygroscopic aerosols like sea salt and sulphates which are also highly scattering have an enormous affinity towards 
water vapour which can result in a change in their physical properties and therefore optical properties like asymmetry parameter. The $S_{\text {unitp }}$ for a change in the asymmetry parameter from 0.55 to 0.65 was calculated to be $\sim 36 \mathrm{~W} \mathrm{~m}^{-2}\left(38 \mathrm{~W} \mathrm{~m}^{-2}\right)$ and $\sim 43 \mathrm{~W} \mathrm{~m}^{-2}\left(45 \mathrm{~W} \mathrm{~m}^{-2}\right)$ for absorbing and scattering aerosols, respectively, during January (May). However, the $R$ of the asymmetry parameter over BoB was 0.047 and 0.046 during January and May, respectively (table 1), resulting in the sensitivity $S$ to be $\sim 1.7 \mathrm{~W} \mathrm{~m}^{-2}\left(1.75 \mathrm{~W} \mathrm{~m}^{-2}\right)$ and $2 \mathrm{~W} \mathrm{~m}^{-2}\left(2.06 \mathrm{~W} \mathrm{~m}^{-2}\right)$ for absorbing and scattering aerosols, respectively (figure $2 \mathrm{~b}$ ). While sensitivity due to the change in the asymmetry parameter increased with the increase in SSA, there was negligible change when the height of the aerosol changed between months. There was a change of $\sim 2 \mathrm{~W} \mathrm{~m}^{-2}$ in $S_{\text {unitp }}$ between the months for the same SSA. This effect, however, is very little over the $\mathrm{BoB}$ due to the small variation in the asymmetry parameter.

$\mathrm{AE}$ is a good representation of aerosol size the higher the value of the $\mathrm{AE}$, the smaller the size of aerosol (Kaufman et al. 1994). Andrews et al. (2006) showed that the asymmetry parameter increased with the increase in aerosol mean volume diameter. Sviridenkov et al. (2017) also showed using models that the asymmetry parameter increased with the decrease in the $\mathrm{AE}$ (increase in size). The AE parameter has been widely used to characterise different types of aerosols (Eck et al. 1999; Reid et al. 1999; Smirnov et al. 2002, 2003). It has also been shown that the wavelength dependence of $\mathrm{AE}$ results in a curvature in the relationship between AOD and wavelength which depends on the aerosol type and fine-mode fraction (Eck et al. 1999; Kaskaoutis et al. 2007). Surface albedo over oceans is very low and uniform. Hence the effect of a change in albedo has a negligible effect on the TOA forcing. However, this is not the case when the underlying surface has varying albedo like continental land surfaces or high surface albedo like snow or ice.

Water vapour in the atmosphere is found to be high within the BL (Parameswaran and Krishna Murthy 1990) and decreases almost exponentially as the altitude increases. Due to the low surface albedo of oceans, the interaction with radiation is only due to the aerosols, gases which absorb like water vapour, methane, ozone, carbon dioxide and also gases like nitrogen and oxygen which cause Rayleigh scattering. Water vapour acts as a strong absorber of radiation even in the visible and near-IR region (Eldridge 1967). In the absence of water vapour, irrespective of the height, scattering aerosols scatter more radiative flux at the TOA and more negative forcing. The presence of water vapour, an absorber, reduces the flux further for both absorbing and scattering aerosols. Hence, the presence of water vapour (compared to a dry atmosphere) causes a reduction in the TOA flux. Markowicz et al. (2003) have shown that a change in relative humidity $(50-95 \%)$ resulted in a change in the TOA aerosol forcing efficiency of $2.5 \mathrm{~W} \mathrm{~m}^{-2} \tau^{-1}$. He attributed this to the change in the optical properties like SSA, AOD and the asymmetry parameter due to the change in relative humidity. However, in the visible spectrum, relative humidity is shown to have a negligible effect on SSA due to the more substantial effect of moisture on the scattering coefficient than on the absorption coefficient of aerosols (Nessler et al. 2005). This was attributed to the dominant presence of scattering aerosols and also to the fact that the increase in moisture had a larger effect on scattering than absorption. While the sensitivity of the TOA aerosol forcing due to the change in water vapour was less compared to the sensitivity to aerosol parameters, the role of the water vapour profile along with the aerosol layer height is important in the amount of radiation reflected at the TOA when aerosols are present under a wet atmosphere, which is discussed in section 3.2.

\subsection{Effect of SSA on aerosol forcing}

Four cases are simulated to understand the effect of a change in SSA (cases 5-8, table 3 ). The results are shown in figure 3.

After AOD, the factor that affects the TOA forcing is the SSA. It has been shown that even a small change in the SSA can cause the forcing due to the change from the negative to the positive, resulting in the warming of the atmosphere (Hansen et al. 1997; IPCC 2013). SSA is defined as the ratio of scattering efficiency to total extinction efficiency, or, in other words, the ratio of radiation scattered by an aerosol layer to the total extinction of radiation by an aerosol layer. Aerosols like sulphate and sea-salt have SSA close to unity, implying that they scatter almost all the radiation, resulting in the cooling of the atmosphere (Haywood and Ramaswamy 1998; Satheesh and Moorthy 2005). On the other hand, absorbing aerosols like $\mathrm{BC}$ and dust absorb radiation and cause a warming of the atmosphere. SSA of 


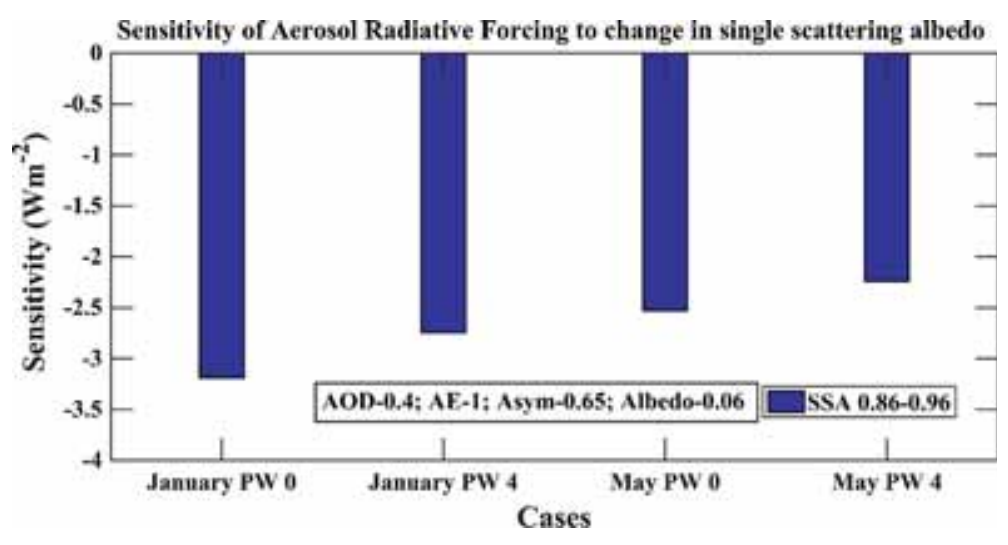

Figure 3. Sensitivity of ARF due to the change in SSA under a dry and wet atmosphere with other properties set as constant.

freshly generated $\mathrm{BC}$ has been found to be $0.1-0.28$ (Bond and Bergstrom 2006; Bond et al. 2013). SSA depends on the aerosol composition, aerosol size distribution and wavelength (Haywood and Shine 1995; Lee et al. 2007; Kazadzis et al. 2010). A study by Srivastava et al. (2017) shows that accounting for the non-sphericity (regardless of the shape) of dust aerosols affected the SSA values (increase by 0.04), and therefore, the estimation of the TOA flux over Delhi.

From figure 3, it is seen that when precipitable water vapour of $4 \mathrm{~cm}$ is added to the atmosphere, the sensitivity value decreases. The decrease is because water vapour acts as an absorber and under a wet atmosphere when the aerosols change from absorbing to scattering, the affinity to water vapour increases, resulting in a change in the physical property of aerosols. When an aerosol layer is present at a higher altitude (during May), it interacts with the incoming radiation as well as the radiation scattered by the atmosphere below. When the layer is absorbing and if the albedo of the underlying surface is high, there is enhanced absorption due to the additional interaction with the atmosphere below the aerosol layer, leading to a positive forcing at the TOA. Scattering aerosols show less dependence on the change in aerosol layer height especially when molecular absorption of water vapour is negligible (dry atmosphere) (Mishra et al. 2015). The dependency changes in the presence of water vapour. Hence a change in the SSA will have a higher effect on aerosol forcing when aerosols are present at a higher altitude both in the presence and absence of water vapour. $S_{\text {unitp }}$ for a change in SSA from 0.86 to 0.96 (absorbing to scattering aerosols) was estimated to be $-56 \mathrm{~W} \mathrm{~m}^{-2}\left(-48 \mathrm{~W} \mathrm{~m}^{-2}\right)$ and $-60 \mathrm{~W} \mathrm{~m}^{-2}\left(-53 \mathrm{~W} \mathrm{~m}^{-2}\right)$ for January and May, respectively, for a dry (wet - PW $4 \mathrm{~cm}$ ) atmosphere. However, figure 3 shows that when aerosols were present closer to the surface (January), the effect of a change in SSA was higher than for elevated aerosols. The reason is due to the higher $R$ in January compared to May (table 1). The higher range of SSA (spatial variation) in January is due to the presence of aerosols from different sources. During winter, the northern BoB is seen to be affected mainly by anthropogenic aerosols from the subcontinent and central and southern BoB is influenced by south-east Asia and the Oceanic regions (Moorthy et al. 2003; Satheesh et al. 2006b; Kaskaoutis et al. 2011). There is also a significant influence of biomass burning aerosols, which are highly absorbing, during winter when compared to other seasons (Kedia et al. 2012). Despite the southern BoB showing less aerosol loading, a large AOD was found in the northern BoB and closer to the coast, resulting in considerable heterogeneity of aerosol properties across the entire region (Sinha et al. 2011), whereas, in May, the most dominant aerosol type is elevated aerosol of both anthropogenic and natural origins (Satheesh et al. 2008). The roles of water vapour and aerosol layer height on aerosol forcing for absorbing and scattering aerosols are discussed in detail in section 3.2 .

\subsection{Effect of water vapour and aerosol layer height on the TOA forcing}

Water vapour, being a strong absorber especially in the near-IR region, affects the TOA flux both in the presence and absence of aerosols, and therefore affects aerosol forcing as well (figure 4).

As water vapour is added to the atmosphere, the TOA forcing increases (reduction in the TOA flux). In the presence of aerosols, the interaction of water vapour-aerosol-radiation is complex. 


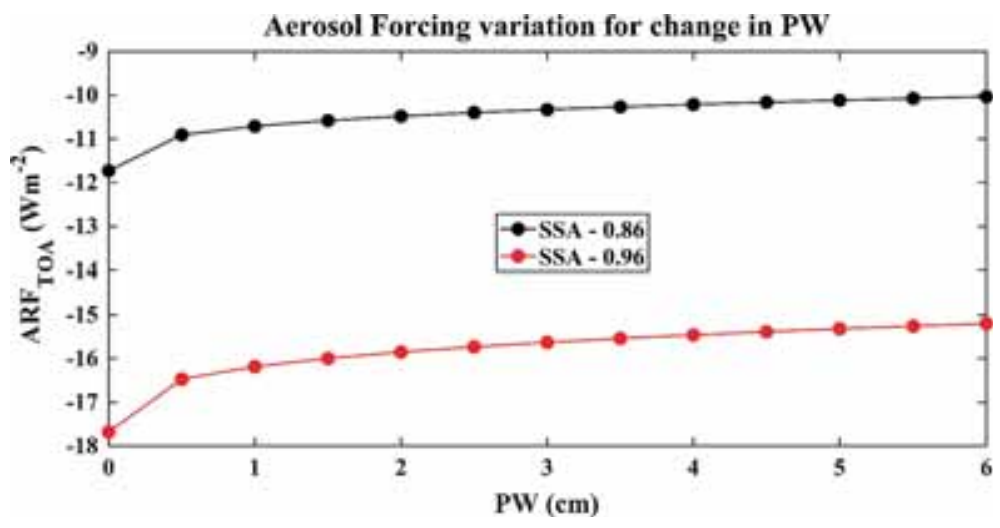

Figure 4. Effect of water vapour on the aerosol forcing at the TOA over an ocean surface for absorbing (black) and scattering (red) aerosols.
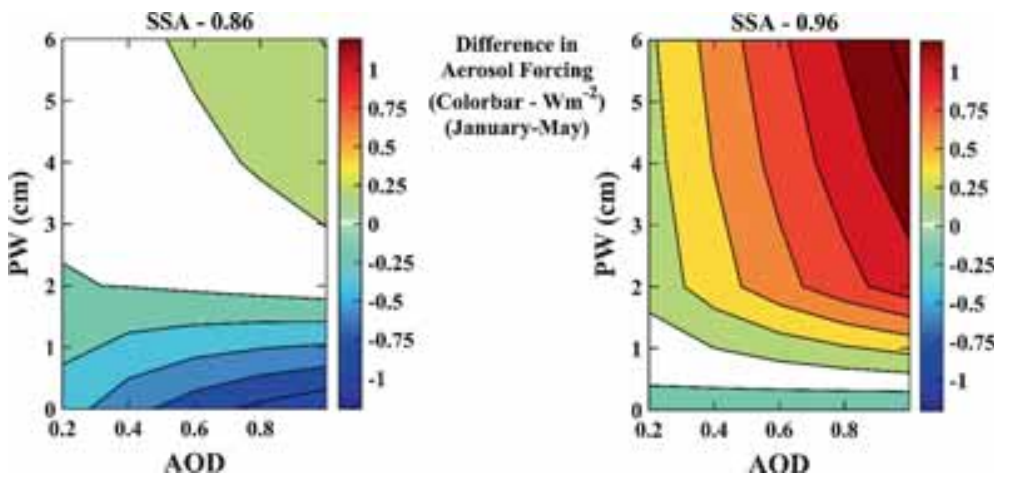

Figure 5. Difference in $\mathrm{ARF}_{\mathrm{TOA}}$ between January and May for absorbing and scattering aerosols and for different AOD and $\mathrm{PW}$. The white contour represents a difference of $\sim 0$.

The difference in $\mathrm{ARF}_{\mathrm{TOA}}$ between January and May for absorbing and scattering aerosols and for different AOD and PW is shown in figure 5.

As mentioned earlier, the $\mathrm{ARF}_{\mathrm{TOA}}$ over oceans is negative. Therefore, from figure 5 if the difference in aerosol forcing is negative, it implies that, during May, there is higher aerosol forcing, resulting in a reduction in the TOA flux and an increase in flux when there is a positive difference. A difference of 0 is shown in white in figure 5 . As the months change from January to May, in an atmosphere with low or negligible water vapour, forcing increases (almost as high as $1 \mathrm{~W} \mathrm{~m}^{-2}$ ) as AOD increases for absorbing aerosols (SSA - 0.86). The more the aerosol loading of absorbing aerosols, the more the absorption of radiation above and below the aerosol layer, resulting in a higher reduction of the TOA flux. However, when the amount of water vapour starts to increase, the absorption due to water vapour masks the effect due to aerosols. In a wet atmosphere, water vapour plays an important role in aerosol forcing especially when scattering aerosols are present. It can be seen from figure 5 that for high water vapour content, as AOD increases, the forcing decreases as the aerosol layer moves from the surface to a higher altitude (January-May). When AOD increases, the flux reaching the TOA increases for both scattering aerosols and absorbing aerosols. However, the rate at which flux increases is more for scattering aerosols than absorbing aerosols. As the amount of water vapour in the atmosphere increases, the flux reaching the TOA is reduced due to absorption by water vapour. However, for the aerosol layer present at an elevated position, the layer interacts with radiation before it reaches the water vapour layer closer to the surface.

The role of the aerosol layer height is studied by simulating the flux at different aerosol heights from the surface to $6 \mathrm{~km}$ and calculating the difference in the TOA flux for aerosol at each height and aerosol close to the surface. The various environmental and aerosol properties were fixed as AOD: 0.4, AE: 1, asymmetry parameter $(g): 0.65$ and surface albedo: 0.06. Tropical atmosphere is assumed in this particular simulation for SSA 0.86 and 0.96 and total column water vapour 0 and $4 \mathrm{~cm}$ (figure 6).

In a dry atmosphere, i.e., PW: $0 \mathrm{~cm}$, absorbing aerosols show more dependence on the aerosol height than scattering aerosols. This is because as the height increases, the amount of radiation 


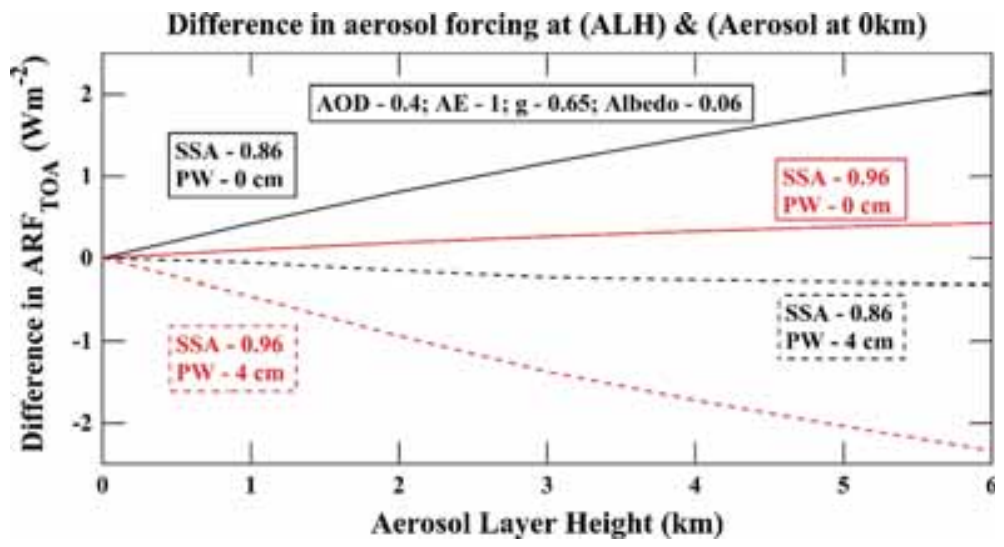

Figure 6. Difference in $\mathrm{ARF}_{\mathrm{TOA}}$ between aerosols present at different heights and those present closer to the surface. The black solid and dashed lines represent absorbing aerosols (SSA -0.86$)$ for a dry $(\mathrm{PW}=0)$ and wet $(\mathrm{PW}=4 \mathrm{~cm})$ atmosphere, respectively. The red lines represent the same but for scattering aerosols (SSA - 0.96).

available for absorption is more due to the scattered radiation by particles present in the atmosphere below the layer. Hence, the amount of flux also decreases as the aerosol layer height increases, increasing aerosol forcing. In a study by Mishra et al. (2015), it was seen that scattering aerosol depended lesser on the aerosol height than absorbing aerosols (e.g., dust) under a dry atmosphere dominated by Rayleigh scattering. The presence of water vapour (PW: $4 \mathrm{~cm}$ ) creates an opposite effect on the outgoing flux at the TOA for different aerosol types at different heights. As water vapour increases, the molecular absorption also increases. When scattering aerosols are present at a higher altitude, the radiation received will interact with the aerosol layer before reaching the atmosphere below which contains absorbers like water vapour. This results in a higher flux at the TOA than the flux due to the aerosol layer at a lower altitude. The effect of water vapour absorption at different aerosol layer heights is shown greater for scattering aerosols than absorbing aerosols (Mishra et al. 2015). The study also showed that in the solar spectrum of $0.25-4 \mu \mathrm{m}$, the role of vertical aerosol distribution is different in the ultraviolet (UV) spectrum and the visible-near infrared (IR) spectrum. While aerosol absorption plays an important role in the UV spectrum, molecular absorption plays a vital role in the visible spectrum.

\subsection{Analytical representation of the role of aerosol layer position on the TOA flux}

The fraction of incoming radiation reflected at the TOA was calculated for the aerosol layer present within the BL and present above the BL using a simple atmospheric model assuming single scattering. The model is based on the Seinfeld and Pandis (2006), aerosol layer model. In a cloud-free atmosphere, radiation interacts with aerosols, molecules like water vapour and gases (like nitrogen and oxygen), resulting in the scattering and absorption of radiation. While aerosols scatter and absorb radiation based on the aerosol type, small particles (including gases like nitrogen and oxygen) result in molecular or Rayleigh scattering. On the other hand, water vapour and gases like ozone, carbon dioxide act as absorbers of radiation. The transmittance of an atmospheric layer is the fraction of radiation that is transmitted through the layer without absorption or reflection. In the model, the transmittance due to the aerosol layer, gases that cause Rayleigh scattering and those that result in molecular absorption are given by $T_{\mathrm{a}}, T_{\mathrm{r}}$ and $T_{\mathrm{m}}$, respectively. When radiation is scattered by particles, some fraction is scattered upwards and the remaining in the downward direction. For aerosols, the fraction of radiation scattered into the upper hemisphere is given by the parameter, $\beta$, and for Rayleigh scattering, it is assumed that radiation is scattered equally on both the directions, i.e., $=0.5$. $\mathrm{SSA}$, a fraction of radiation scattered by aerosols, is given by the parameter, $\omega$. Single scattering has been assumed for simplicity.

When aerosols are present within the BL, the incident radiation interacts with aerosols and other atmospheric particles/molecules simultaneously. The fraction of radiation reflected at the TOA is given by equation (2):

$$
\begin{aligned}
F_{\mathrm{TOA}}= & T_{\mathrm{m}}\left[\left(0.5 * T_{\mathrm{a}} *\left(1-T_{\mathrm{r}}\right)\right)\right. \\
& \left.+\left(\omega \beta T_{\mathrm{r}} *\left(1-T_{\mathrm{a}}\right)\right)\right] .
\end{aligned}
$$


The fraction reflected at the TOA depends on the transmittance of molecules and the relative dominance of scattering of aerosols and the Rayleigh scattering. When aerosols are present above the $\mathrm{BL}$, the radiation interacts with the aerosol layer separately before interacting with particles within the BL. No aerosols are assumed to be present in the BL. Equation (3) gives the fraction of reflected radiation at the TOA:

$$
\begin{aligned}
& F_{\mathrm{TOA}}=\left[\omega \beta *\left(1-T_{\mathrm{a}}\right)\right] \\
& \quad+\left[\left(T_{\mathrm{a}}+\left(\omega(1-\beta)\left(1-T_{\mathrm{a}}\right)\right)\right) *\left(0.5 * T_{\mathrm{m}} *\left(1-T_{\mathrm{r}}\right)\right)\right] .
\end{aligned}
$$

Since the aerosol layer is assumed to be independent of the other atmospheric particles, the fraction of radiation at the TOA depends on the properties of the aerosol layer separately which is given by the first term. The second term represents the effect of the atmospheric layer, including Rayleigh scattering and molecular absorption, on the total (direct+diffuse) radiation transmitted downwards through the aerosol layer.

To further understand the effect of aerosol layer height, the sensitivity of the fraction of incoming radiation reflected at the TOA due to the change of various parameters used in the simple model is calculated (figure 7).

Whether the aerosol layer is within or above the BL, figure 7 shows that the primary parameter that affects the amount of radiation reflected back to the space is the up-scatter fraction $(\beta)$, i.e., the fraction of radiation scattered by aerosols into the upper hemisphere. This fraction is related to the solar zenith angle and aerosol size (Seinfeld and Pandis 2006; Hassan et al. 2015). The up-scatter fraction has been used as a function of the asymmetry parameter before, either linearly (Sagan and Pollack 1967; Chylek and Wong 1995) or as a complex function (Wiscombe and Grams 1976; Fiebig and Ogren 2006). Hence, the amount of radiation reflected at the TOA depends heavily on the amount scattered by an aerosol layer into the upward hemisphere or indirectly on the amount of radiation scattered in the forward direction (asymmetry parameter). The effect is slightly more for aerosols with higher SSA that are highly scattering when compared to absorbing aerosols.

When an aerosol layer is present within the BL, apart from aerosols, there are gases like nitrogen and oxygen that cause Rayleigh scattering and molecules like water vapour which act as a strong absorber. The main factor affecting the amount of radiation at the TOA apart from $\beta$ is the transmittance of absorbers like water vapour $\left(T_{\mathrm{m}}\right)$. The transmittance of a layer is related to the optical thickness of the layer $(\tau)$, i.e., $T=\mathrm{e}^{-\tau}$, approximated as $1-\tau$ for $\tau<1$. Regardless of the type of aerosol, the absorption due to water vapour $\left(T_{\mathrm{m}}\right)$ affects the TOA radiation more than the interaction between aerosols and radiation $\left(T_{\mathrm{a}}\right.$ or SSA).

The optical properties of aerosol play a more active role than water vapour in affecting the radiation at the TOA when the aerosol is above the BL. The transmittance of the aerosol layer is indirectly related to AOD as shown earlier and hence whether the aerosol is absorbing or scattering, the higher the AOD (the lower the transmittance), the higher the radiation scattered back to the TOA. The next dominant factor is the SSA. Here the role of water vapour is lesser when compared to the scenario of aerosol within the BL. There is still absorption of water vapour, but the presence of the aerosol layer above the BL results in radiation interacting with the aerosol layer before reaching the BL.

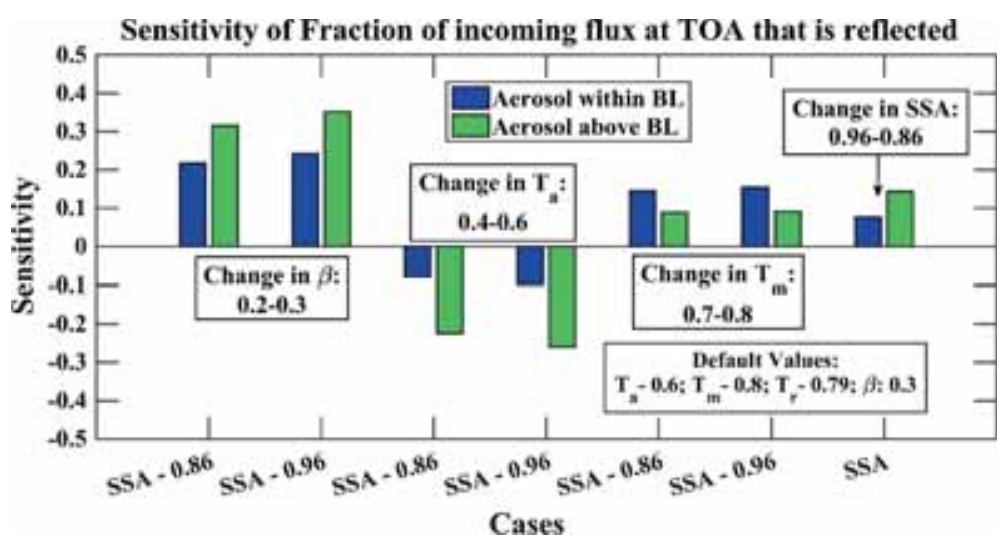

Figure 7. Sensitivity of fraction of incoming radiation at the TOA reflected the change in various parameters used in the model for aerosols within the BL (blue) and aerosol above BL (green). 


\section{Conclusion}

Aerosol forcing depends on the aerosol amount, type and composition. Estimates of aerosol forcing are affected by the uncertainty and the accuracy in the measurements of various aerosol optical properties. The major properties that affect aerosol forcing are the AOD, SSA and the asymmetry factor. The present study uses the SBDART model to analyse the impact of various aerosol properties on the TOA aerosol forcing. Two typical profiles over the $\mathrm{BoB}$ representing the aerosol layer as above (May) and within the BL (January) have been used. The following conclusions were observed:

- The maximum sensitivity in aerosol forcing was due to AOD. Over oceans, as AOD increased, the effect of aerosol on the TOA forcing also increased. The sensitivity was higher for scattering aerosols. It was also high during May than January as the variation in aerosols was large when there was a transition from winter to the summer monsoon.

- Following AOD, the most significant contributor to the variation in the TOA forcing is SSA. The maximum effect of SSA on forcing was seen in January than May due to the broader range of SSA over the BoB during January. The presence of water vapour does not affect the influence of SSA on forcing.

- The effect of asymmetry parameter and AE is high for scattering aerosols because in the presence of moisture, scattering aerosols like sea-salt which are hygroscopic can change their size and hence their optical properties as well.

- The effect of water vapour on the TOA flux and forcing depends on the position of the aerosol layer. When aerosols are present within the BL, absorption due to water vapour affects the TOA flux more than the interaction between aerosols and radiation. The optical properties of aerosols are more effective than those of water vapour in affecting the radiation at the TOA when the aerosol layer is present above the BL.

- In a dry atmosphere, the radiative flux reaching the TOA depends on the aerosol layer height when the amount of absorbing aerosols is more than that of scattering aerosols. As the amount of water vapour increases, the TOA flux depends on the aerosol layer height when scattering aerosols are more in quantity than absorbing aerosols.
For the accurate estimation of global forcing and to study the effect of aerosols on climate, the uncertainty in the measurements of various aerosol optical properties has to be reduced. Presently, the measurements of AOD have been reasonably accurate. However, the retrievals of SSA and vertical aerosol distribution are still uncertain, and more closure studies have to be performed. With the present remote-sensing scenario including the A-train constellation, various satellites carrying different sensors can be used simultaneously to study the atmosphere and its components more accurately. In the present work, the direct effect of water vapour on aerosol forcing has been studied. Water vapour absorption plays a vital role in aerosol forcing. The effect is maximum for scattering aerosols which have a higher affinity towards water vapour than strongly absorbing aerosols. Aerosol layer height affected aerosol forcing based on the amount of water vapour present in the atmosphere. The relationship between water vapour content throughout the atmosphere and the vertical aerosol distribution during clear skies have to be analysed further in detail using satellites and other means of measurement. Such studies can help us estimate either of these properties when the other is available.

\section{Acknowledgements}

The authors are grateful to the NASA data and services centre for providing MODIS, OMI, CERES and CALIPSO data used in this study to understand the vertical profiles of aerosols.

\section{References}

Allen M R and Ingram W J 2002 Constraints on future changes in climate and the hydrologic cycle; Nature 419 224-232, https://doi.org/10.1038/nature01092.

Anderson B T, Knight J R, Ringer M A, Deser C, Philips A S, Yoon J-H and Cherchi A 2010 Climate forcings and climate sensitivities diagnosed from atmospheric global circulation models; Clim. Dyn. 35(4) 1461-1475, https:// doi.org/10.1007/s00382-010-0798-y.

Andrews E, Sheridan P J, Fiebig M, McComiskey A, Ogren J A, Arnitt P, Covert D, Elleman R, Gasparini R, Collins D, Jonsoon H, Schmid B and Wang J 2006 Comparison of methods for deriving aerosol asymmetry parameter; J. Geophys. Res.-Atmos. 111(D5), https://doi.org/10. 1029/2004JD005734.

Angstrom A K 1929 On the atmospheric transmission of sun radiation and on the dust in the air; Geografiska Annaler 11 156-166, https://doi.org/10.2307/519399. 
Babu S S, Satheesh S K, Moorthy K K, Dutt C B S, Nair V S, Alappattu D P and Kunhikrishnan P K 2008 Aircraft measurements of aerosol black carbon from a coastal location in the north-east part of peninsular India during ICARB; J. Earth Syst. Sci. 117(1) 263-271, https://doi. org/10.1007/s120140-008-0030-1.

Bauer S, Bierwirth E, Esselborn M, Petzold A, Macke A, Trautmann T and Wendisch M 2011 Airborne spectral radiation measurements to derive solar radiative forcing of Saharan dust mixed with biomass burning smoke particles; Tellus B 63(4) 742-750, https://doi.org/10.1111/ j.1600-0889.2011.00567.x.

Bellouin N, Boucher O, Haywood J and Reddy M S 2005 Global estimate of aerosol direct radiative forcing from satellite measurements; Nature 438 1138-1141, https:// doi.org/10.1038/nature04348.

Bergamo A, Tafuro A M, Kinne S, De Tomasi F and Perrone M R 2008 Monthly-averaged anthropogenic aerosol direct radiative forcing over the Mediterranean based on AERONET aerosol properties; Atmos. Chem. Phys. 8(23) 6995-7014, https://doi.org/10.5194/ acp-8-6995-2008.

Boer G J 1993 Climate change and the regulation of the surface moisture and energy budgets; Clim. Dyn. 8(5) 225-239, https://doi.org/10.1007/BF00198617.

Bond T C and Bergstrom R W 2006 Light absorption by carbonaceous particles: An investigative review; Aer. Sci. Tech. 40(1) 27-67, https://doi.org/10.1080/ 02786820500421521.

Bond T C, Doherty S J, Fahey D W, Forster P M, Bernsten T, De Angelo B J, Flanner M G, Ghan S, Karcher B, Koch D, Kinne S, Kondo Y, Quinn P K, Sarofim M C, Schultz M, Venkataraman C, Zhang H, Zhang S, Bellouin N, Guttikunda S K, Hopke P K, Jacobson M Z, Kaiser J W, Klimont Z, Lohmann U, Schwarz J P, Shindell D, Storelvmo T, Warren S G and Zender C S 2013 Bounding the role of black carbon in the climate system: A scientific assessment; J. Geophys. Res. 118(11) 5380-5552, https:// doi.org/10.1002/jgrd.50171.

Boucher O, Randall D, Artaxo P, Bretherton C, Feingold G, Forster P, Kerminen V-M, Kondo Y, Liao H, Lohmann U, Rasch P, Satheesh S K, Sherwood S, Stevens B and Zhang X Y 2013 Clouds and aerosols; In: Climate change 2013: The physical science basis. Contributions of working group I to the fifth assessment report of the intergovernmental panel on climate change (eds) Stocker T F, Qin D, Plattner G-K, Tignor M, Allen S K, Boschung J, Nauels A, Xia Y, Bex V and Midgley P M, Cambridge University Press, Cambridge, UK and New York, NY, USA, pp. 571-658, https://doi.org/10.1017/ CBO9781107415324.016.

Breon F-M, Tanre D and Generoso S 2002 Aerosol effect on cloud droplet size monitored from satellite; Science 295(5556) 834-838, https://doi.org/10.1126/ science.1066434.

Carslaw K S, Boucher O, Spracklen D V, Mann G W, Rae J G L, Woodward S and Kulmala M A 2010 Review of natural aerosol interactions and feedbacks within the Earth system; Atmos. Chem. Phys. 10 1701-1737, https://doi. org/10.5194/acp-10-1701-2010.

Charlson R J, Schwartz S E, Hales J M, Cess R D, Coakley Jr J A, Hansen J E and Hofmann D J 1992 Climate forcing by anthropogenic aerosols; Science 255(5043) 423-430, https://doi.org/10.1126/science.255.5043.423.

Charlson R J, Valero F P J and Seinfeld J H 2005 In search of balance; Science 308(5723) 806-807, https://doi.org/ 10.1126/science.1108162.

Chen L, Shi G, Qin S, Yang S and Zhang P 2011 Direct radiative forcing of anthropogenic aerosols over oceans from satellite observations; Adv. Atmos. Sci. 28(4) 973-984, https://doi.org/10.1007/s00376-010-9210-4.

Christopher S A and Jones T A 2008 Shortwave aerosol radiative efficiency over the global oceans derived from satellite data; Tellus B 636-640, https://doi.org/10.1111/ j.1600-0889.2008.00353.x.

Christopher S A and Zhang J 2002 Shortwave aerosol radiative forcing from MODIS and CERES observations over the oceans; Geophys. Res. Lett. 29(18) 1859, https://doi. org/10.1029/2002GL014803.

Chung C E, Chu J-E, Lee Y, van Nojie T, Jeoung H, Ha K-J and Marks M 2016 Global direct radiative forcing as constrained by comprehensive observations; Atmos. Chem. Phys. Diss. in review, https://doi.org/10.5194/ acp-2016-30.

Chylek P and Wong J 1995 Effect of absorbing aerosols on global radiation budget; Geophys. Res. Lett. 22(8) 929 931, https://doi.org/10.1029/95GL00800.

Coakley Jr J A and Cess R D 1985 Response of the NCAR community climate model in the radiative forcing by the naturally occurring tropospheric aerosol; $J$. Atmos. Sci. 42(16) 1677-1692, https://doi.org/10.1175/ 1520-0469(1985)042<1677:ROTNCC > 2.0.CO;2.

Coakley Jr J A, Cess R D and Yurevich F B 1983 The effect of tropospheric aerosols on the Earth's Radiation Budget: A parameterization for climate models; J. Atmos. Sci. 40(1) 116-138, https://doi.org/10.1175/ 1520-0469(1983)040<0116:TEOTAO>2.0.CO;2.

Curry J 1995 Interactions among aerosols, clouds, and climate of the Arctic ocean; Sci. Total Environ. 160, 777791, https://doi.org/10.1016/0048-9697(95)04411-S.

Curry J A and Webster P J 2011 Climate science and the uncertainty monster; Bull. Am. Meteorol. Soc. 92(12) 1667-1682, https://doi.org/10.1175/2011BAMS3139.1.

Di Biagio C, di Sarra A and Meloni D 2010 Large atmospheric shortwave radiative forcing by Mediterranean aerosols derived from simultaneous ground-based and spaceborne observations and dependence on the aerosol type and single scattering albedo; J. Geophys. Res. 115(D10), https://doi.org/10.1029/2009JD012697.

Dubovik O, Smirnov A, Holben B N, King M D, Kaufman Y J, Eck T F and Slutsker I 2000 Accuracy assessments of aerosol optical properties retrieved from Aerosol Robotic Network (AERONET) sun and sky radiance measurements; J. Geophys. Res. 105(D8) 9791-9806, https://doi. org/10.1029/2000JD900040.

Eck T F, Holben B N, Reid J S, Dubovik O, Smirnov A, O'Neill N T, Slutsker I and Kinne S 1999 Wavelength dependence of the optical depth of biomass burning, urban, and desert dust aerosols; J. Geophys. Res. 104(D24) 31333-31349, https://doi.org/10.1029/ 1999JD900923.

Eldridge R G 1967 Water vapour absorption of visible and near infrared radiation; Appl. Opt. 6(4) 709-713, https:// doi.org/10.1364/AO.6.000709. 
Feng Y, Kotamarthi V R, Coulter R, Zhao C and Cadeddu M 2015 Radiative and thermodynamic responses to aerosol extinction profiles during the pre-monsoon month over South Asia; Atmos. Chem. Phys. 16(1) 247-264, https:// doi.org/10.5194/acp-16-247-2016.

Fiebig M and Ogren J A 2006 Retrieval and climatology of the aerosol asymmetry parameter in the NOAA aerosol monitoring network; J. Geophys. Res. 111(D21), https:// doi.org/10.1029/2005JD006545.

Halthore R N and Schwartz S E 2000 Comparison of model-estimated and measured diffuse downward irradiance at surface in cloud-free skies; J. Geophys. Res. 105(D15) 20165-20177, https://doi.org/10.1029/ 2000JD900224.

Halthore R N, Crisp D, Schwartz S E, Anderson G P, Berk A, Bonnel B, Boucher O, Chang F-L, Chou MD, Clothiaux E E, Dubuisson P, Fomin B, Fouquart Y, Freidenreich S, Gautier C, Kato S, Laszlo I, Li Z, Mather J H, Plana-Fattori A, Ramaswamy V, Ricchiazzi P, Shiren Y, Trischenko A and Wiscombe W 2005 Intercomparison of shortwave radiative transfer codes and measurements; J. Geophys. Res. 110(D11), https://doi. org/10.1029/2004JD005293.

Hansen J, Sato M and Ruedy R 1997 Radiative forcing and climate response; J. Geophys. Res.-Atmos. 102(D6) 6831-6864, https://doi.org/10.1029/96JD03436.

Hansen J E, Sato M, Lacis A, Ruedy R, Tegen I and Matthews E 1998 Climate forcings in the industrial era; Proc. Natl. Acad. Sci. 95(22) 12753-12758, https://doi. org/10.1073/pnas.95.22.12753.

Hansen J, Sato M, Ruedy R, Lacis A and Oinas V 2000 Global warming in the twenty-first century: An alternative scenario; Proc. Natl. Acad. Sci. 98(18) 9875-9880, https://doi.org/10.1073/pnas.170278997.

Hansen J, Nazarenko L, Ruedy R, Sato M, Willis J, Del Genio A, Koch D, Lacis A, Lo K, Menon S, Novakov T, Perlwitz J, Russell G, Schmidt G A and Tausnev N 2005 Earth's energy imbalance: Confirmation and implications; Science 308(5727) 1431-1435, https://doi.org/10.1126/ science. 1110252 .

Hassan T, Moosmuller H and Chung C E 2015 Coefficients of an analytical aerosol forcing equation determined with a Monte-Carlo radiation model; J. Quant. Spectrosc. Radiat. Transf. 164 129-136, https://doi.org/10.1016/j. jqsrt.2015.05.015.

Haywood J M and Ramaswamy V 1998 Global sensitivity studies of the direct radiative forcing due to anthropogenic sulfate and black carbon aerosols; J. Geophys. Res. 103(D6) 6043-6058, https://doi.org/10.1029/ 97JD03426.

Haywood J M and Shine K P 1995 The effect of anthropogenic sulfate and soot aerosol on the clear sky planetary radiation budget; Geophys. Res. Lett. 22, https://doi.org/ 10.1029/95GL00075.

Heintzenberg J, Hermann M, Weigelt A, Clarke A, Kapustin V, Anderson B, Thornhill K, van Velthoven P, Zahn A and Brenninkmeijer C 2011 Near-global aerosol mapping in the upper troposphere and lowermost stratosphere with data from the CARIBIC project; Tellus B 63(5) 875-890, https://doi.org/10.1111/j.1600-0889.2011.00578.x.

Houghton J T, Jenkins G J and Ephraums J J $1990 \mathrm{Cli}$ mate change: The IPCC scientific assessment; Cambridge
University Press, Cambridge, Great Britain, New York, NY, USA and Melbourne, Australia, 410p.

Intergovernmental Panel on Climate Change (IPCC) 2013 The physical science basis: Contribution of working group I to the fifth assessment report of the intergovernmental panel on climate change; In: Climate change (eds) Stocker T F, Qin D, Plattner G K, Tignor M, Allen S K, Boschung J, Nauels A, Xia Y, Bex V and Midgley P M, Cambridge University Press, Cambridge, UK and New York, NY, USA, 1535p, https://doi.org/10.1017/ CBO9781107415324.

Kahn R A 2012 Reducing the uncertainties in direct aerosol radiative forcing; Surv. Geophys. 33(3-4) 701721, https://doi.org/10.1007/s10712-011-9153-z.

Kaskaoutis D G, Kambezidis H D, Hatzianastassiou N, Kosmopoulos P G and Badarinath K V.S 2007 Aerosol climatology: Dependence of the Angstrom exponent on wavelength over four AERONET sites; Atmos. Chem. Phys. Diss. 7 7347-7397, https://doi.org/10.5194/ acpd-7-7347-2007.

Kaskaoutis D G, Kharol S K, Sinha P R, Singh R P, Kambezidis H D, Sharma A R and Badarinath K V S 2011 Extremely large anthropogenic-aerosol contribution to total aerosol load over the Bay of Bengal during winter season; Atmos. Chem. Phys. 11 7097-7117, https://doi. org/10.5194/acp-11-7097-2011.

Kaufman Y J and Koren I 2006 Smoke and pollution aerosol effect on cloud cover; Science 313(5787) 655-658, https://doi.org/10.1126/science.1126232.

Kaufman Y J, Gitelson A, Karnieli A, Ganor E, Fraser R S, Nakajima T, Mattoo S and Holben B N 1994 Size distribution and scattering phase function of aerosol particles retrieved from sky brightness measurements; $J$. Geophys. Res. 99(D5) 10,341-10,356, https://doi.org/10. 1029/94JD00229.

Kaufman Y J, Koren I, Remer L A, Rosenfeld D and Rudich Y 2005 The effect of smoke, dust, and pollution aerosol on shallow cloud development over the Atlantic Ocean; Proc. Natl. Acad. Sci. 102(32) 11,207-11,212, https://doi.org/ 10.1073/pnas.0505191102.

Kazadzis S, Grobner J, Arola A and Amiridis V 2010 The effect of the global UV irradiance measurement accuracy on the single scattering albedo retrieval; Atmos. Meas. Tech. 3 1029-1037, https://doi.org/10. 5194/amt-3-1029-2010.

Kedia S, Ramachandran S, Rajesh T A and Srivastava R 2012 Aerosol absorption over Bay of Bengal during winter: Variability and sources; Atmos. Environ. 54 738-745, https://doi.org/10.1016/j.atmosenv.2011.12.047.

Kiehl J T and Briegleb B P 1993 The relative roles of sulfate aerosols and greenhouse gases in climate forcing; Science 260(5106) 311-314, https://doi.org/10.1126/ science.260.5106.311.

Knutti R, Stocker T F, Joos F and Plattner G-K 2002 Constraints on radiative forcing and future climate change from observations and climate model ensembles; Nature 416 719-723, https://doi.org/10.1038/416719a.

Kokhanovsky A A, Deuze J L, Diner D J, Dubovik O, Ducos F, Emde C, Garay M J, Grainger R G, Heckel A, Herman M, Katsev I L, Keller J, Levy R, North P R J, Prikhach A S, Rozanov V V, Sayer A M, Ota Y, Tanre D, Thomas G E and Zege E P 2010 The inter-comparison 
of major satellite aerosol retrieval algorithms using simulated intensity and polarization characteristics of reflected light; Atmos. Meas. Tech. 3 909-932, https://doi.org/10. 5194/amt-3-909-2010.

Kumar K R, Narasimhulu K, Balakrishnaiah G, Reddy B S K, Gopal K R, Reddy R R, Reddy L S S, Moorthy K K, Babu S S and Dutt C B S 2011 Spatial heterogeneities in aerosol properties over Bay of Bengal inferred from shipborne and MODIS observations during W-ICARB cruise campaign: Implications to radiative forcing; Atmos. Environ. 45(2) 404-412, https://doi.org/10.1016/j.atmosenv. 2010.10.004.

Kumar K R, Sivakumar V, Reddy R R and Gopal K R 2013 Ship-borne measurements of columnar and surface aerosol loading over the Bay of Bengal during W-ICARB campaign: Role of airmass transport. Latitudinal and longitudinal gradients; Aerosol. Air. Qual. Res. 13 818-837, https://doi.org/10.4209/aaqr.2012.08.0225.

Lakshmi N B, Nair V S and Babu S S 2017 Vertical structure of aerosols and mineral dust over the Bay of Bengal from multisatellite observations; J. Geophys. Res. 122 12,84512,861, https://doi.org/10.1002/2017JD027643.

Lee K H, Li Z, Wong M S, Xin J, Wang Y, Hao W-M and Zhao F 2007 Aerosol single scattering albedo estimated across China from a combination of ground and satellite measurements; J. Geophys. Res. 112 D22S15, https://doi. org/10.1029/2007JD009077.

Lee L A, Reddington C L and Carslaw K S 2015 On the relationship between aerosol model uncertainty and radiative forcing uncertainty; Proc. Natl. Acad. Sci., https://doi. org/10.1073/pnas. 1507050113.

Li Z, Zhao Z, Kahn R, Mishchenko M, Remer L, Lee K-H, Wang M, Laszlo I, Nakajima T and Maring H 2009 Uncertainties in satellite remote sensing of aerosols and impact on monitoring its long-term trend: A review and perspective; Ann. Geophys. 27 2755-2770, https://doi.org/ 10.5194/angeo-27-2755-2009.

Liao H and Seinfeld J H 1998 Radiative forcing by mineral dust aerosols: Sensitivity to key variables; J. Geophys. Res.-Atmos. 103(D24) 31,637-31,645, https://doi.org/ 10.1029/1998JD200036.

Lin N-H, Sayer A M, Wang S-H, Loftus A M, Hsiao T-C, Sheu G-R, Hsu N C, Tsay S-C and Chantara S 2014 Interactions between biomass-burning aerosols and clouds over Southeast Asia: Current status, challenges and perspectives; Environ. Pollut. 195 292-307, https://doi.org/10. 1016/j.envpol.2014.06.036.

Loeb N G and Manalo-Smith N 2005 Top-of-atmosphere direct radiative effect of aerosols over global oceans from merged CERES and MODIS observations; J. Clim. 18(17) 3506-3526, https://doi.org/10.1175/ JCLI3504.1.

Loeb N G and Su W 2010 Direct aerosol radiative forcing uncertainty based on a radiative perturbation analysis; J. Clim. 23(19) 5288-5293, https://doi.org/10.1175/ 2010JCLO3543.1.

Lohmann U and Lesins G 2002 Stronger constraints on the anthropogenic indirect aerosol effect; Science 298(5595) 1012-1015, https://doi.org/10.1126/science.1075405.

Lohmann U, Quaas J, Kinne S and Feichter J 2007 Different approaches for constraining global climate models of the anthropogenic indirect aerosol effect; Bull. Am.
Meteorol. Soc. 88(2) 243-249, https://doi.org/10.1175/ BAMS-88-2-243.

Markowicz K M, Flatau P J, Quinn P K, Carrico C M, Flatau M K, Vogelmann A M, Bates D, Liu M and Rood M J 2003 Influence of relative humidity on aerosol radiative forcing: An ACE-Asia experiment perspective; J. Geophys. Res. 108(D23) 8662, https://doi.org/10. 1029/2002JD003066.

McComiskey A, Schwartz S E, Schmid B, Guan H, Lewis E R, Ricchiazzi P and Ogren J A 2008 Direct aerosol forcing: Calculation from observables and sensitivities to inputs; J. Geophys. Res.-Atmos. 113(D9), https://doi.org/10. 1029/2007JD009170.

Michalsky J J, Anderson G P, Barnard J, Delamere J, Gueymard C, Kato S, Kiedron P, McComiskey A and Ricchiazzi P 2006 Shortwave radiative closure studies for clear skies during the atmospheric radiation measurement 2003 aerosol intensive observation period; J. Geophys. Res. 111 D14S90, https://doi.org/10.1029/2005JD006341.

Mishra A K, Koren I and Rudich Y 2015 Effect of aerosol vertical distribution on aerosol-radiation interaction: A theoretical prospect; Heliyon e00036, https://doi.org/10. 1016/j.heliyon.2015.e00036.

Mitchell J F B 1983 The seasonal response of a general circulation model to changes in $\mathrm{CO}_{2}$ and sea temperatures; Quart. J. Roy. Meteorol. Soc. 109(459) 113-152, https:// doi.org/10.1002/qj.49710945906.

Mitchell J F B, Wilson C A and Cunnington W M 1987 On $\mathrm{CO}_{2}$ climate sensitivity and model dependence of results; Quart. J. Roy. Meteorol. Soc. 113(475) 293-322, https:// doi.org/10.1002/qj.49711347517.

Mitchell J F B, Johns T C, Eagles M, Ingram W J and Davis R A 1999 Towards the construction of climate change scenarios; Clim. Change 41(3-4) 547-581, https://doi.org/ 10.1023/A:1005466909820.

Moorthy K K, Babu S S and Satheesh S K 2003 Aerosol spectral optical depths over the Bay of Bengal: Role of transport; Geophys. Res. Lett. 30(5) 1249, https://doi. org/10.1029/2002GL016520.

Moorthy K K, Satheesh S K, Babu S S and Dutt C B S 2008 Integrated campaign for aerosols, gases and radiation budget (ICARB): An overview; J. Earth Syst. Sci. 117(1) 243-262, https://doi.org/10.1007/s12040-008-0029-7.

Moorthy K K, Beegum S N, Babu S S, Smirnov A, John S R, Kumar K R, Narasimhulu K, Dutt C B S and Nair V S 2010 Optical and physical characteristics of Bay of Bengal aerosols during W-ICARB: Spatial and vertical heterogeneities in the marine atmospheric boundary layer and in the vertical column; J. Geophys. Res. 115(D24) D24213, https://doi.org/10.1029/2010JD014094.

Myhre G 2009 Consistency between satellite-derived and modelled estimates of the direct aerosol effect; Science 325 187, https://doi.org/10.1126/science.1174461.

Myhre G, Bellouin N, Berglen T F, Berntsen T K, Boucher O, Grini A, Isaksen I S A, Johnsrud M, Mishchenko M I, Stordal F and Tanre D 2007 Comparison of the radiative properties and direct radiative effect of aerosols from a global aerosol model and remote sensing data over ocean; Tellus B 59(1) 115-129, https://doi.org/10.1111/ j.1600-0889.2006.00226.x.

Myhre G, Shindell D, Breon F-M, Collins W, Fuglestvedt J, Huang J, Koch D, Lamarque J-F, Lee D, Mendoza B, 
Nakajima T, Robock A, Stephens G, Takemura T and Zhang H 2013 Anthropogenic and natural radiative forcing; In: Climate change 2013: The physical science basis. Contributions of working group I to the fifth assessment report of the intergovernmental panel on climate change (eds) Stocker T F, Qin D, Plattner G-K, Tignor M, Allen S K, Boschung J, Nauels A, Xia Y, Bex V and Midgley P $\mathrm{M}$, Cambridge University Press, Cambridge, UK and New York, NY, USA.

Nair V S, Moorthy K K, Babu S S and Satheesh S K 2009 Optical and physical properties of atmospheric aerosols over the Bay of Bengal during ICARB; J. Atmos. Sci. 66 2640-2658.

Nair V S, Babu S S, Moorthy S S and Prijith S S 2013 Spatial gradients in aerosol-induced atmospheric heating and surface dimming over the oceanic regions around India: Anthropogenic or natural? J. Clim. 26 7611-7621. https://doi.org/10.1175/JCLI-D-12-00616.1.

Nemesure S, Wagener R and Schwartz S E 1995 Direct shortwave forcing of climate by the anthropogenic sulfate aerosol: Sensitivity to particle size, composition, and relative humidity; J. Geophys. Res. 100(D12) 26,105-26,116, https://doi.org/10.1029/95JD02897.

Nessler R, Wiengartner E and Baltensperger U 2005 Effect of humidity on aerosol light absorption and its implications for extinction and the single scattering albedo illustrated for a site in the lower free troposphere; J. Aerosol Sci. 36 958-972, https://doi.org/10.1016/j.jaerosci.2004.11.012.

Niranjan K, Madhavan B L and Sreekanth V 2007 Micro pulse lidar observation of high altitude aerosol layers at Visakhapatnam located on the east coast of India; Geophys. Res. Lett. 34(3), https://doi.org/10. 1029/2006GL028199.

Osborne S R, Baran A J, Johnson B T, Haywood J M, Hesse E and Newman S 2011 Shortwave and longwave radiative properties of Saharan dust aerosol; Quart. J. Roy. Meteorol. Soc. 137(658) 1149-1167, https://doi.org/10.1002/ qj. 771 .

Parameswaran K and Krishna Murthy B V 1990 Altitude profiles of tropospheric water vapour at low latitudes; J. Appl. Meteorol. 29 665-679, https://doi.org/10.1175/ 1520-0450(1990)029<0665:APOTWV>2.0.CO;2.

Patadia F and Christopher S A 2014 Assessment of smoke shortwave radiative forcing using empirical angular distribution models; Remote Sens. Environ. 140 233-240, https://doi.org/10.1016/j.rse.2013.08.034.

Penner J E, Charlson R J, Hales J M, Laulainen N, Leifer R, Novakov T, Ogren J, Radke L F, Schwartz S E and Travis L 1994 Quantifying and minimizing uncertainty of climate forcing by anthropogenic aerosols; Bull. Am. Meteorol. Soc. 75 375-400.

Quaas J, Boucher O and Lohmann U 2006 Constraining the total aerosol indirect effect in the LMDZ and ECHAM4 GCMs using MODIS satellite data; Atmos. Chem. Phys. 6 947-955, https://doi.org/10.5194/ acp-6-947-2006.

Raes F, Liao H, Chen W-T and Seinfeld J H 2010 Atmospheric chemistry-climate feedbacks; J. Geophys. Res. 115(D12), https://doi.org/10.1029/2009JD013300.

Ramanathan V and Carmichael G 2008 Global and regional climate changes due to black carbon; Nat. Geosci. $1221-$ 227, https://doi.org/10.1038/ngeo156.
Ramanathan V, Cess R D, Harrison E F, Minnis P, Barkstrom B R, Ahmad E and Hartmann D 1989 Cloud-radiative forcing and climate: Results from the earth radiation budget experiment; Science $\mathbf{2 4 3}(\mathbf{4 8 8 7})$ 57-63, https://doi.org/10.1126/science.243.4887.57.

Reid J S, Eck T F, Christopher S A, Hobbs P V and Holben B N 1999 Use of angstrom exponent to estimate the variability of optical and physical properties of aging smoke particles in Brazil; J. Geophys. Res. 104(D22) 27,47327,489, https://doi.org/10.1029/1999JD900833.

Remer L A and Kaufman Y J 2006 Aerosol direct radiative effect at the top of the atmosphere over cloudfree ocean derived from four years of MODIS data; Atmos. Chem. Phys. 6 237-253, https://doi.org/10.5194/ acp-6-237-2006.

Ricchiazzi P, Yang S, Gautier C and Sowle D 1998 SBDART: A research and teaching software tool for plane-parallel radiative transfer in the earth's atmosphere; Bull. Am. Meteorol. Soc. 79(10) 2101-2114, https://doi.org/10. 1175/1520-0477(1998)079<2101:SARATS > 2.0.CO;2.

Rosenfeld D, Sherwood S, Wood R and Donner L 2014 Climate effects of aerosol-cloud interactions; Science 343(6169) 379-380, https://doi.org/10.1126/ science.1247490.

Sagan C and Pollack J B 1967 Anisotropic nonconservative scattering and the clouds of Venus; J. Geophys. Res. 72(2) 469-477, https://doi.org/10.1029/JZ072i002p00469.

Samset B H, Myhre G and Schulz M 2014 Upward adjustment needed for aerosol radiative forcing uncertainty; Nat. Clim. Chang. 4 230-232, https://doi.org/10.1038/ nclimate2170.

Satheesh S K and Moorthy K K 2005 Radiative effects of natural aerosols: A review; Atmos. Environ. 39(11) 20892110, https://doi.org/10.1016/j.atmosenv.2004.12.029.

Satheesh S K and Ramanathan V 2000 Large differences in tropical aerosol forcing at the top of the atmosphere and earth's surface; Nature 405 60-63, https://doi.org/ $10.1038 / 35011039$.

Satheesh S K, Vinoj V and Moorthy K K 2006a Vertical distribution of aerosols over an urban continental site in India inferred using a micro pulse lidar; Geophys. Res. Lett. 33 L20816, https://doi.org/10.1029/ 2006GL027729.

Satheesh S K, Srinivasan J and Moorthy K K 2006b Spatial and temporal heterogeneity in aerosol properties and radiative forcing over Bay of Bengal: Sources and role of aerosol transport; J. Geophys. Res. 111(D8) D08202, https://doi.org/10.1029/2005JD006374.

Satheesh S K, Moorthy K K, Babu S S, Vinoj V and Dutt C B.S 2008 Climate implications of large warming by elevated aerosol over India; Geophys. Res. Lett. 35(19), https://doi.org/10.1029/2008GL034944.

Schwartz S E 1996 The whitehouse effect - shortwave radiative forcing of climate by anthropogenic aerosols: An overview; J. Aerosol Sci. 27(3), https://doi.org/10.1016/ 0021-8502(95)00533-1.

Schwartz S E 2004 Uncertainty requirements in radiative forcing of climate change; J. Air Waste Manage. Assoc. 54(11) 1351-1359, https://doi.org/10.1080/ 10473289.2004.10471006.

Seinfeld J H and Pandis S N 2006 Atmospheric chemistry and physics: From air pollution to climate change (2nd 
edn), John Wiley \& Sons, Inc. Hobkoben, New Jersey, 1232p.

Sinha P R, Manchanda R K, Kaskaoutis D G, Sreenivasan S, Moorthy K K and Babu S S 2011 Spatial heterogeneities in aerosol size distribution over Bay of Bengal during winter-ICARB experiment; Atmos. Environ. 45(27) 4695-4706, https://doi.org/10.1016/j.atmosenv.2011.04. 085 .

Smirnov A, Holben B N, Kaufman Y J, Dubovik O, Eck T F, Slutsker I, Pietras C and Halthore R N 2002 Optical properties of atmospheric aerosol in maritime environments; J. Atmos. Sci. 59(3) 501-523, https://doi.org/10. 1175/1520-0469(2002)059<0501:OPOAAI > 2.0.CO;2.

Smirnov A, Holben B N, Dubovik O, Frouin R, Eck T F and Slutsker I 2003 Maritime component in aerosol optical models derived from Aerosol Robotic Network data; J. Geophys. Res. 108(D1) AAC 14-1-AAC 14-11, https:// doi.org/10.1029/2002JD002701.

Srivastava P, Dey S, Srivastava A K, Singh S, Mishra S K and Tiwari S 2017 Importance of aerosol non-sphericity in estimating aerosol radiative forcing in Indo-Gangetic Basin; Sci. Total Environ. 599-600 655-662, https://doi. org/10.1016/j.scientotenv.2017.04.239

Stevens B 2015 Rethinking the lower bound on aerosol radiative forcing; J. Clim. 28(12) 4794-4819, https://doi.org/ 10.1175/JCLI-D-14-00656.1.

Subrahamanyam D B, Anurose T J, Kiran Kumar N V P, Mohan M, Kunhikrishnan P K, John S R, Prijith S S and Dutt C B S 2012 Spatial and temporal variabilities in vertical structure of the marine atmospheric boundary layer over Bay of Bengal during winter phase of integrated campaign for aerosols, gases and radiation budget; Atmos. Res. 107 178-185, https://doi.org/10.1016/j. atmosres.2011.12.014.

Sviridenkov M A, Mikhailov E F and Nebos'ko E $\mathrm{Yu} 2017$ Parameterization of asymmetry factor of atmospheric aerosol scattering phase function; Atmos.
Ocean. Opt. 30(5) 435-440, https://doi.org/10.1134/ S102485601705013X.

Tao K-W, Chen J-P, Li Z, Wang C and Zhang C 2012 Impact of aerosols on convective clouds and precipitation; Rev. Geophys. 50(2), https://doi.org/10.1029/ 2011RG000369.

Twomey S 1991 Aerosols, clouds and radiation; Atmos. Environ. A Gen. Top. 25(11) 2435-2442, https://doi.org/10. 1016/0960-1686(91)90159-5.

Vuolo M R, Schulz M, Balkanski Y and Takemura T 2014 A new method for evaluating the impact of vertical distribution on aerosol radiative forcing in general circulation models; Atmos. Chem. Phys. 14 877-897, https://doi.org/ 10.5194/acp-14-877-2014.

Wiscombe W J and Grams G W 1976 The backscattered fraction in two-stream approximations; J. Atmos. Sci. 33(12) 2440-2451, https://doi.org/10.1175/ 1520-0469(1976)033<2440:TBFITS > 2.0.CO;2.

Yu H and Zhang Z 2013 New directions: Emerging satellite observations of above-cloud aerosols and direct radiative forcing; Atmos. Environ. 72 36-40, https://doi.org/10. 1016/j.atmosenv.2013.02.017.

Yu H, Kaufman Y J, Chin M, Feingold G, Remer L A, Anderson T L, Balkanski Y, Bellouin N, Boucher O, Christopher S, DeCola P, Kahn R, Koch D, Loeb N, Reddy M S, Schulz M, Takemura T and Zhou M 2006 A review of measurement-based assessments of the aerosol direct radiative effect and forcing; Atmos. Chem. Phys. 6 613-666, https://doi.org/10.5194/acp-6-613-2006.

Zarzycki C M and Bond T C 2010 How much can the vertical distribution of black carbon affect its global direct radiative forcing? Geophys. Res. Lett. 37 L20807, https://doi. org/10.1029/2010GL044555.

Zhang J, Christopher S A, Remer L A and Kaufman Y J 2005 Shortwave aerosol radiative forcing over cloud-free oceans from terra: 2. Seasonal and global distributions; J. Geophys. Res. 110 D10S24. 